\title{
Paleoenvironmental significance of clay mineral assemblages in the southeastern Arabian Sea during last $30 \mathrm{kyr}$
}

\author{
Siddhartha Sankar Das ${ }^{1, *}$, Ajai $\mathrm{K} \mathrm{Rai}^{1}$, Vaseem Akaram ${ }^{1}$, Dhananjai Verma ${ }^{1}$, \\ A C Pandey ${ }^{2}$, Koushik Dutta ${ }^{3,4}$ and G V Ravi Prasad ${ }^{3,5}$ \\ ${ }^{1}$ Department of Earth \&3 Planetary Sciences, University of Allahabad, Allahabad 211 002, India. \\ ${ }^{2}$ Department of Ocean 83 Atmospheric Studies, University of Allahabad, Allahabad 211 002, India. \\ ${ }^{3}$ Institute of Physics, Bhubaneswar 751 005, India. \\ ${ }^{4}$ University of Minnesota, Duluth, MN 55812, USA. \\ ${ }^{5}$ University of Georgia, Athens, GA 30602, USA. \\ ${ }^{*}$ Corresponding author.e-mail: siddharthasankardas.alld@gmail.com
}

\begin{abstract}
A gravity core SK-221 recovered from the southeastern Arabian Sea near Laccadive-Chagos Ridge was examined to identify the sources of detrital clay minerals and to decipher paleoenvironmental changes for the last $30 \mathrm{kyr}$. The clay mineral assemblages predominantly consist of illite, kaolinite and chlorite with small amounts of smectite. Quartz, feldspar and occasionally gibbsite are the clay-sized non-clay minerals present in the examined section. The detrital clay minerals primarily originated from the hinterland and were supplied to the present site by the numerous small rivers draining western India during preglacial and Holocene periods, and partly by the strong reworking of Indian continental shelf during glacial period. The low values of humidity proxies (kaolinite content, kaolinite to illite and smectite to illite ratios) and better illite crystallinity indicate relatively weak summer monsoon condition that resulted in reduced chemical weathering during glacial period, which was interrupted by a discrete event of winter monsoon intensification at $\sim 20-17 \mathrm{ka}$. The increased kaolinite content, higher values of humidity indices and poorer illite crystallinity reflect high humidity that resulted in strong hydrolysis activity during the preglacial and Holocene periods. The increased $\mathrm{CaCO}_{3}$ during above periods also indicates less terrigenous dilution and intensified southwest monsoon-led upwelling which result in higher surface biogenic productivity. The characteristic clay mineral associations broadly suggest dry to semi-drier conditions during Heinrich Events H1, H2, and H3 and also during Younger Dryas. The low values of biogenic carbonate and organic carbon also indicate low productivity associated with weak summer monsoons during Heinrich Events. Abrupt increased humidity was recorded at 15-12.7 ka (Bølling/Allerød Event) sandwiched between two lows of Heinrich Events. Cycles of millennial timescale variations 2300, 1800, 1300 and 1000 yr have been observed from the clay mineralogical data. All the cycles observed in the monsoonal climate appear to be part of global oscillations.
\end{abstract}

\section{Introduction}

Clay minerals are common components in most marine sediments, especially those deposited on the continental margins, where there is a significant terrigenous input (Biscaye 1965). The climate change controls continental weathering rates and runoff, which in turn influences soil formation and

Keywords. Arabian Sea; clay mineral; Holocene; monsoon; western India. 
transport of terrigenous material into the sea. The detrital clay minerals, end product of continental weathering processes, are considered a useful key to the past changes in weathering regime (Chamley 1989, 1997; Thiry 2000; Adatte et al. 2002). The sedimentation of detrital clay minerals in marine environment takes place mainly through fluvial and/or eolian pathways. About $95 \%$ of terrigenous material in the ocean is conveyed by rivers and is deposited on continental margins (Rea and Leinen 1988). In theory, marine sediments may store a record of the environmental conditions and allow comparing these with changes in oceanographic circulation and with global temperatures also (Dou et al. 2010). Presuming that geology and geomorphology of the source region remained fairly stable for the time period in consideration in a tropical region, rainfall seems to be main factor determining the composition of clay minerals in marine sediments (Singer 1984; Thamban et al. 2002). Clay mineral composition basically indicates the intensity of weathering, especially the degree of hydrolysis at source region which can be used as paleoclimatic indicator (Chamley 1989; Sirocko and Lange 1991; Thiry 2000; Thamban et al. 2002; Zhifei et al. 2003; Dou et al. 2010). The diagenetic effects on Recent marine clay minerals are considered to be insignificant and therefore the provenance of different clay minerals can be identified (Grim 1968).

Previous studies of clay mineral composition of marine sediments from continental margin of western India were mainly based on surficial sediments and were used to understand the provenance and transport pathways of fine-grained terrigenous sediments (Kolla et al. 1981; Chauhan 1994; Kessarkar et al. 2003). The general relationship between the lithology and weathering regime of a continental source area was established on global scale by Griffin et al. (1968) and Kolla et al. (1981) to interpret the clay mineral abundance data from surface sediments of the western Indian Ocean and the Arabian Sea. The clay mineralogy of the gravity core samples collected from the continental margin of India near Goa and Cochin have been studied by Thamban et al. (2002) and Kessarkar et al. (2003). Naidu and Shankar (1999) discussed the paleomonsoon history of late Quaternary based on a pilot study of sediments from the shallower levels of Laccadive Trough. Pattan et al. (2003) discussed the productivity variations in the south eastern Arabian Sea for the last $140 \mathrm{ka}$ by using multiple geochemical proxies.

In this paper, we present a high-resolution record of clay mineral assemblages in a gravity core SK221 collected from southeastern Arabian Sea near Laccadive-Chagos Ridge ( $8^{\circ} 7.12^{\prime} \mathrm{N}, 73^{\circ} 16.38^{\prime} \mathrm{E}$; water depth $2188 \mathrm{~m}$ ). The main objectives are: (i) to document temporal variation in quantitative input of terrigenous material to this site, (ii) to record clay mineral assemblages and sources for the past $\sim 30 \mathrm{kyr}$, and (iii) to correlate between clay mineral assemblages and paleoenvironmental changes during the last $30 \mathrm{kyr}$.

\section{Materials and methods}

\subsection{Geological and oceanographic settings}

The study area lies in the tropical belt and experiences monsoon climate with seasonally reversing wind patterns and large related changes in precipitation (figure 1). Summer monsoons account for the main part of very high rainfall recorded in this region $(>3000 \mathrm{~mm}$ ), whereas winter monsoons are less important as far as rainfall is concerned (Thamban et al. 2002). The Western Ghats mountain range is the major physiographic feature all along western peninsular India. The Deccan Trap basalts are the characteristic rocks in the north of Goa; and Precambrian gneisses, schists and charnockites are the predominant rock types in the region between Goa and Cochin. Several small and medium rivers originate from these regions and drain their detritus into the Arabian Sea. The width of continental shelf in the western margin of India varies widely between $\sim 130 \mathrm{~km}$ off Ratnagiri and $60 \mathrm{~km}$ off Cochin (Rao and Wagle 1997). The

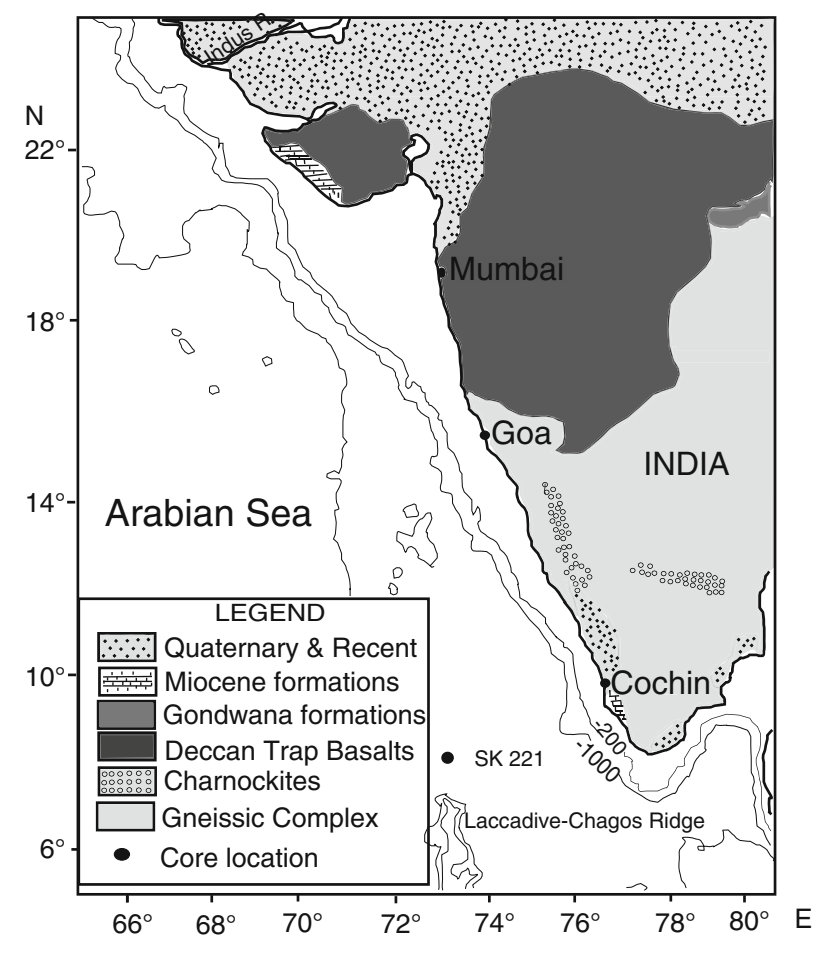

Figure 1. Location map of the core SK-221 in southeastern Arabian Sea with bathymetric contours. Major rock types are shown for peninsular India (redrawn after Thamban et al. 2002). 
Arabian Sea circulation is greatly influenced by the strong seasonal monsoon wind patterns. During the southwest monsoon, there is clockwise circulation of wind within the basin and it reverses the direction during northeast monsoon period (Honjo et al. 1999). A southerly coastal current was reported below $50 \mathrm{~m}$ water depth along Indian coast during southwest monsoon and is replaced by a northerly current during the northeast monsoon (Shetye et al. 1990).

\subsection{Collection of gravity core SK-221}

A 5.5-m long gravity core (SK-221) was collected from southeastern Arabian Sea near LaccadiveChagos Ridge during ORV Sagar Kanya cruise 221. The present study is based on the samples taken from the top $1 \mathrm{~m}$ of the core. For the purpose of clay mineralogical study, the samples were collected at $1.0-\mathrm{cm}$ interval from top $52 \mathrm{~cm}$ of core and at $3.0-\mathrm{cm}$ interval for the rest. The samples for the organic carbon analysis were taken at $1-\mathrm{cm}$ interval.

\subsection{Analytical methods for clay mineralogy and organic carbon}

All together, 67 samples were used for clay mineralogical study. To minimize the inaccuracies associated with sample mounting procedures, instrumental settings were kept constant and identical sample preparation and quantification procedures were followed. Oven-dried samples were decalcified with 20\% hydrochloric acid. Excess acid was removed by repeated rinsing with distilled water and centrifuging. The dried residue was again treated with $30 \%$ hydrogen peroxide to remove organic matter. Particles of $<2 \mu \mathrm{m}$ size were separated by using Stoke's Law and concentrated by centrifuging. Oriented clay slides of each sample were prepared by pipetting clay solution on glass slides and air dried prior to X-ray diffraction (XRD) analysis. The XRD analyses were conducted using a Rigaku X-ray Diffractometer (Ni-filtered $\mathrm{Cu} \mathrm{K}$-alpha radiation, $40-\mathrm{kV}$ voltage, and 20-mA intensity). The air dried and ethyleneglycolated (glycolated at $100^{\circ} \mathrm{C}$ for 1 hour) clay slides were scanned from $5^{\circ}$ to $40^{\circ} 2 \theta$ and $5^{\circ}$ to $10^{\circ} 2 \theta$, respectively, at $2^{\circ} 2 \theta / \mathrm{min}$. Slow scan XRD from 24 to $26^{\circ} 2 \theta$ at $1^{\circ} 2 \theta / \mathrm{min}$ was also carried out for each slide. All minerals were identified (Moore and Reynolds 1997) and their peak areas were obtained using DMS software of peak-fitting function. Relative abundance of different minerals such as illite $(10 \AA)$, kaolinite $(3.57 \AA)$, chlorite $(14 \AA)$, smectite $(17 \AA)$, quartz $(4.26 \AA)$ and plagioclase feldspar (3.19 $\AA$ ) was evaluated semi-quantitatively from their peak areas (Robert and Kennett 1997; Mallison et al. 2003). As the 3.57 and $3.54 \AA$ doublets of kaolinite and chlorite did not resolve well in each sample, the $3.57 \AA$ peak area was considered for kaolinite. The $14 \AA$ chlorite peak was used for semi-quantitative study. This peak also gives similar result as the $3.54 \AA$ chlorite peak in the relative abundance study (Biscaye 1965). The clay data were thus reported in relative abundance without correction factors. The 'crystallinity', a measure of the lattice ordering was measured as the halfheight width of the illite $10 \AA$ peak. Illite chemistry was assessed from the $5 / 10 \AA$ peak area ratio. Alrich illites (muscovite) have values $>0.5$, whereas $\mathrm{Mg}$ - and Fe-rich illites have values $<0.15$ (Esquevin 1969; Gingele 1996). Kaolinite to illite (K/I) and smectite to illite $(\mathrm{Sm} / \mathrm{I})$ ratios were also calculated for each sample.

Organic carbon content of 97 samples from this core was also estimated by titration method suggested by Gaudette et al. (1974).

\subsection{Age-model from ${ }^{14} \mathrm{C}$ dating}

The age model is mainly based on the three AMS ${ }^{14} \mathrm{C}$ dates in planktonic foraminifer samples separated from three depths $(0-1,50-51$, and 100-102 cm). Sample preparation was carried out at the Institute of Physics AMS Laboratory, Bhubaneswar, India. The planktonic foraminifer samples were first pretreated with $0.1 \mathrm{~N} \mathrm{HCl}$ for $10 \mathrm{~s}$ to remove surficial secondary calcareous deposits, and cleaned in deionized water with ultrasonication. The dried foram samples were then reacted with $85 \% \mathrm{H}_{3} \mathrm{PO}_{4}$ under vacuum. The liberated $\mathrm{CO}_{2}$ was cryogenically purified and converted to graphite by $\mathrm{H}_{2}$ reduction over Fe catalyst, and finally pressed into targets for $\mathrm{AMS}{ }^{14} \mathrm{C}$ analysis. The ${ }^{14} \mathrm{C}$ measurements were carried out at AMS facility of the Center for Applied Isotope Studies, University of Georgia, Athens, USA, using a NEC 1.5 SDH-1 0.5MV AMS system. The ${ }^{14} \mathrm{C}$-ages are reported as BP (years before present) after normalizing for the isotopic fractionation of ${ }^{13} \mathrm{C}$ (Stuiver and Polach 1977). Calibration was done using Calib 6.0 radiocarbon calibration software (Stuiver and Reimer 1993), and Marine04 calibration curve (Hughen et al. 2004). Mean $\Delta$ - $R$ correction value of $138 \pm 64$ years was used for the study region (Dutta et al. 2001; Southon et al. 2002).

Both the raw ${ }^{14} \mathrm{C}$ ages and the calibrated ages are given in table 1 . The age of the core top $(0-1 \mathrm{~cm})$ is $2285 \pm 60 \mathrm{cal} \mathrm{BP}$ and the $100-102 \mathrm{~cm}$ level is $30173 \pm 180 \mathrm{cal} \mathrm{BP}$. The average sedimentation rate for the core was $\sim 3.6 \mathrm{~cm} \mathrm{ka}^{-1}$ over the period of study. 
Table 1. AMS ${ }^{14} C$ dates in core $S K$-221.

\begin{tabular}{lcc}
\hline Sample & $\begin{array}{c}\text { Measured } \\
14 \text { C-age (BP) }\end{array}$ & $\begin{array}{c}\text { Calibrated } \\
\text { 14 C-age (cal BP) }\end{array}$ \\
\hline SK-221/GC 0-1 cm & $2396 \pm 23$ & $2285 \pm 60$ \\
SK-221/GC 50-51 cm & $21187 \pm 60$ & $25195 \pm 120$ \\
SK-221/GC 100-102 cm & $25215 \pm 76$ & $30173 \pm 180$ \\
\hline
\end{tabular}

\subsection{Spectral analysis methods}

To determine the major modes of periodicities in the clay mineral concentrations, we have done spectral analysis of the clay mineral data using the software package SPECTRUM (Schulz and Stattegger 1997). This software determines the Lomb-Skargle periodogram from unevenly spaced time series. We have used Ofac (over sampling factor) of 6 and Welch I window to determine the power spectrum and significance of the spectral coherence, and the corresponding phases at $90 \%$ confidence limit. The normalized clay mineral time-series data were used for the analyses. We have also analysed a composite clay mineral time-series obtained by adding the concentrations of chlorite, illite, kaolinite, smectite, and feldspar, to determine the overall periodicities of the clay minerals.

\section{Results}

\section{$3.1 \mathrm{CaCO}_{3}$ and organic carbon}

The samples are mainly composed of calcareous clayey silt. Grain-size analyses of the terrigenous fraction show dominance of mud over sand throughout the studied section of the core. The carbonate content of the core SK-221 varied between $66 \%$ and $86 \%$ (av. $77 \%$ ) and shows stepwise increasing and decreasing pattern for the studied period. It shows relatively higher contents during the $\sim 26,22-19,8-6 \mathrm{ka}$ and thereafter it decreased steadily (figure 2). The total organic carbon content (TOC) varies between $0.07 \%$ and $2.4 \%$ (average $0.6 \%$ ) in these samples and show variation pattern almost similar to that of carbonate content. The terrigenous matter content varied between $13 \%$ and $33 \%$ (average $23 \%$ ) and has negative correlation with the total carbonate content (figures 2 and 3 ).

\subsection{Clay mineral results}

Downcore variations of clay and non-clay mineral assemblages are shown in figure 4 . The clay mineral assemblages are dominated by illite (19-51\%, av. $34 \%)$, kaolinite (14-38\%, av. 28\%) and chlorite $(18-41 \%$, av. $28 \%$ ), while smectite (av. $5 \%$ ) is less abundant. Quartz (av. 3.5\%), feldspar (1.5\%)

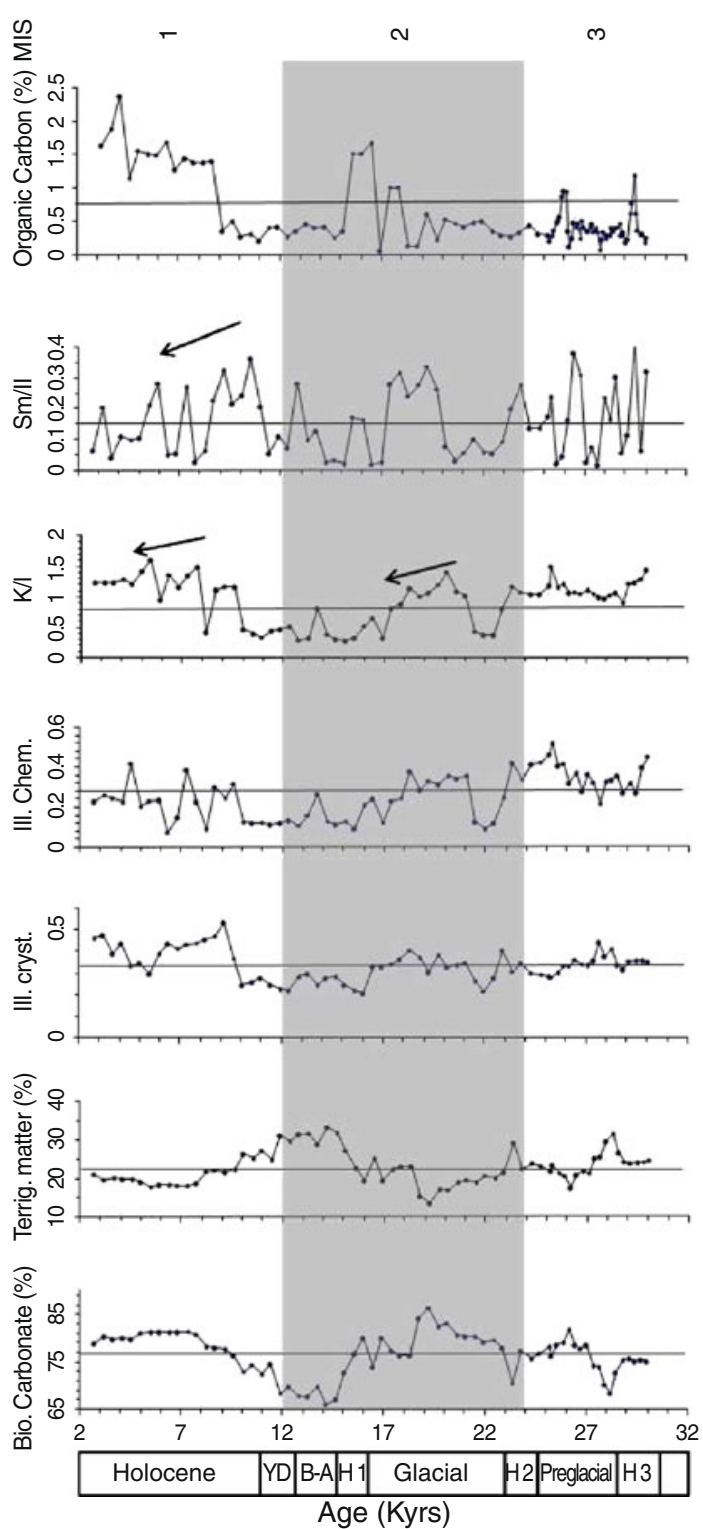

Figure 2. Temporal variability of biogenic carbonate, terrigenous matter, organic carbon, illite crystallinity, illite chemistry and ratios of kaolinite to illite and smectite to illite. H1, H2, H3: Heinrich Events. YD: Younger Dryas, B-A: Bølling/Allerød, MIS: Marine isotopic stages.

and occasionally gibbsite are the clay-sized nonclay minerals present in the examined section. The downcore variations of clay minerals discussed in terms of three major units: Preglacial period $(\sim 30$ $24 \mathrm{ka})$, Glacial period ( $24-10 \mathrm{ka})$ and Holocene (figure 4). Illite content shows higher values during glacial period. A marked fall in illite contents is observed between $\sim 20$ and $17 \mathrm{ka}$. It is noteworthy that the illite content decreased in a stepwise manner during glacial stage. Overall kaolinite and chlorite have similar variations and show inverse relationships with the illite contents. They show relatively higher contents at preglacial and Holocene periods. However, the kaolinite, in 


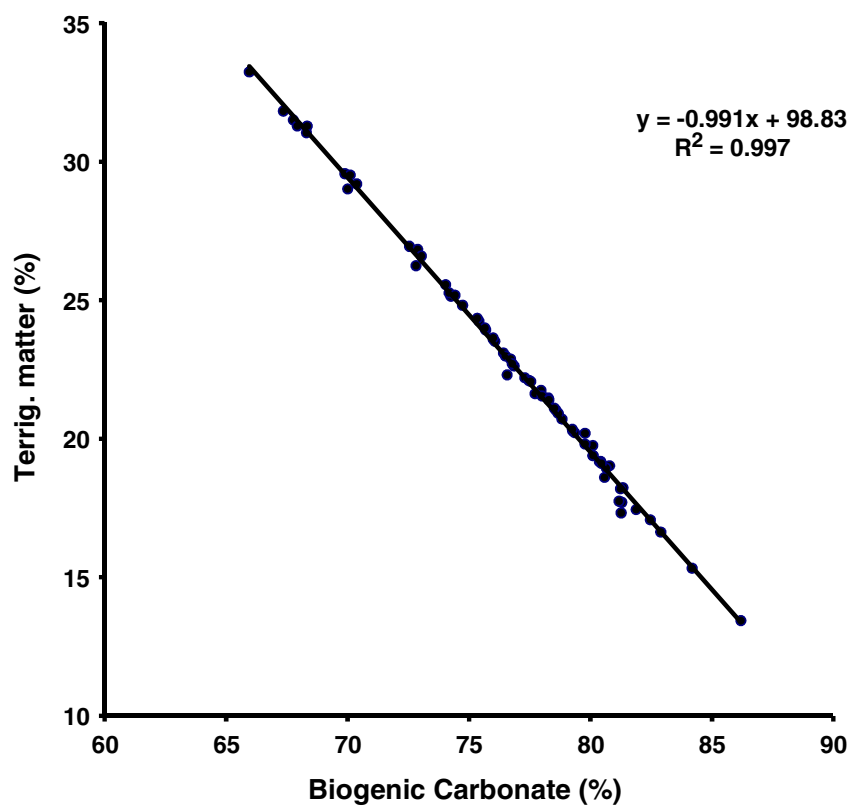

Figure 3. Scatter plot between biogenic carbonate and terrigenous matter.

particular, shows a fall in its content at $\sim 28 \mathrm{ka}$ and a rise in its content between 20 and $17 \mathrm{ka}$. Kaolinite and chlorite show stepwise increasing and decreasing patterns for the studied period. Smectite content shows large down-core fluctuations in the studied section. Non-clay minerals, quartz and feldspar have almost identical variation patterns for the studied period. Both the minerals show slightly higher contents during Holocene and Preglacial periods. Gibbsite, another mineral found in some samples is only relatively high at high kaolinite levels. K/I (kaolinite/illite) and $\mathrm{Sm} / \mathrm{Il}$ (smectite/illite) ratios, which may be used as humidity indices, show relatively lower values during glacial period than preglacial and Holocene (figure 2) periods. However, they show typically higher values between 20 and $17 \mathrm{ka}$ and a downfall at $\sim 28 \mathrm{ka}$. The $\mathrm{K} / \mathrm{I}$ ratio, in particular, shows a stepwise increasing pattern in the Holocene period. Since $\sim 5 \mathrm{ka}$, these indices show significant fall in their values. The illite $5 \AA / 10 \AA$ ratio, an index of illite chemistry, varies between 0.07 and 0.52 (average 0.26 ). The illite data indicate that the illites are relatively rich in $\mathrm{Fe}-\mathrm{Mg}$ and close to biotite. The ratio shows relatively lower values during glacial period. It also showed significant higher values at $\sim 20-17 \mathrm{ka}$ and lower values at $\sim 28 \mathrm{ka}$ (figure 2 ).

The present data when compared to Millennial scale variability indicates that the biogenic carbonate either remained low or decreased during ages $\sim 29.5-28,24.5-23,16-14.8$ and $12.7-11$ ka corresponding to Heinrich Events 1, 2 and 3 (H1, H2 and H3) and Younger Dryas Event (YD), respectively (figure 2). These ages also recorded relatively lower organic matter contents. There is no distinctive change in the above materials recorded during 15$12.7 \mathrm{ka}$, the Bølling/Allerød (B-A) Event. The clay mineralogical signatures and clay-based humidity indices are also correlated with the above events (figure 4). The illite contributed in higher quantities during the $\mathrm{H} 1$ and YD Events, but remained low during $\mathrm{H} 2$ and $\mathrm{H} 3$ events. The kaolinite remained low during the above events. A spike of kaolinite at 15-12.7 ka corresponds to the B-A Event. Chlorite contribution is relatively higher during H3, $\mathrm{H} 2$ and YD. The smectite contribution remained low only during YD. Humidity index K/I either remained low or decreased during the above events.

\subsection{Spectral analysis results of the clay mineral data}

Results of spectral analysis of the individual clay mineral time series are shown in figure 5. Most robust periodicities common for most clay minerals are seen at about 2.3, 1.8, 1.3 ka and near 1 ka.

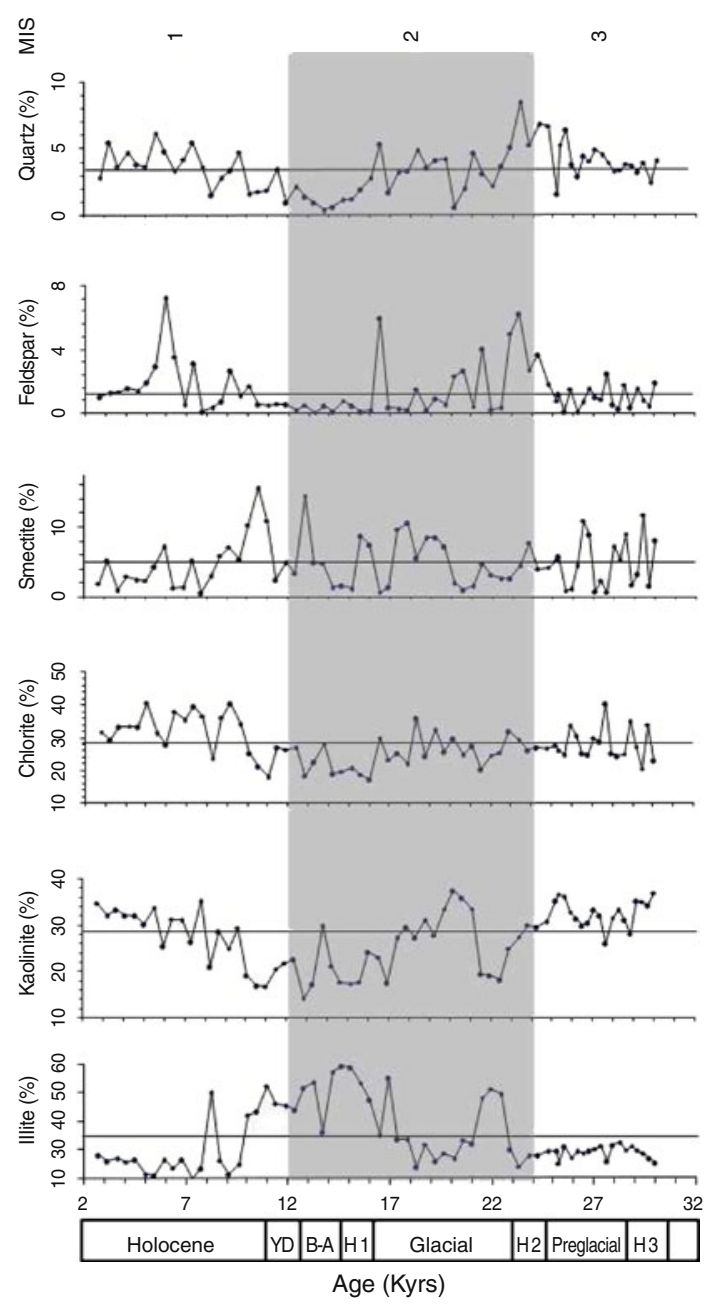

Figure 4. Late Quaternary variations in concentrations of illite, kaolinite, chlorite, smectite, feldspar and quartz. H1, H2, H3: Heinrich Events. YD: Younger Dryas, B-A: Bølling/Allerød, MIS: Marine isotopic stages. 

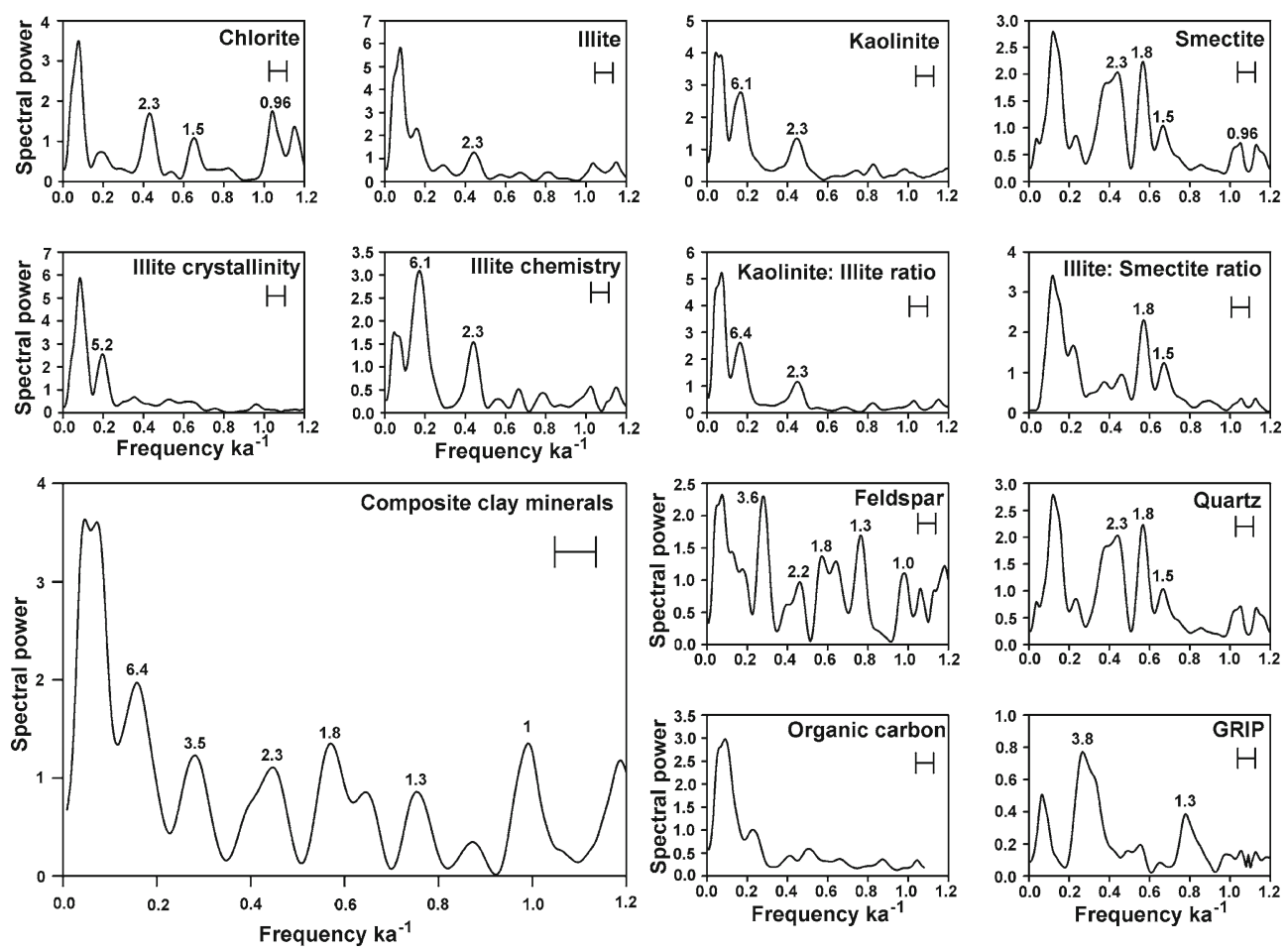

Figure 5. Spectral analysis results of individual clay minerals, mineral ratios and composite clay minerals. Periodicities of significant spectral peaks $(>95 \%)$ are indicated in kilo-years. Horizontal bars $(|-|)$ indicate 6 -dB bandwidth of spectral resolution. No significant periodicities observed for organic carbon in the $1-5$ ka band. Spectral analysis of the GRIP $\delta^{18} \mathrm{O}$ time series is also shown which is obtained for the exact same time period and resolution as the clay minerals.

Kaolinite shows a significant $\sim 6$ ka cycle, but we have ignored the cycles longer than $5 \mathrm{ka}$, which might result from the secular trend in the time series. Feldspar show very prominent $3.6 \mathrm{ka}$ and $1.3 \mathrm{ka}$ cycles, that are also present in the GRIP $\delta^{18} \mathrm{O}$ record for the same time period.

\section{Discussion}

Accumulation of $\mathrm{CaCO}_{3}$ on the sea floor is mainly controlled by the biological productivity in surface water, rate of dissolution through the water column as well as on the sea floor and dilution by terrigenous matter. Calcite compensation depth (CCD) in the Arabian Sea lies below $3500 \mathrm{~m}$ water depth (Cullen and Prell 1984) and the present sediment core was retrieved from water depth of $2188 \mathrm{~m}$ suggesting that dissolution of $\mathrm{CaCO}_{3}$ is negligible. Relatively high calcium carbonate content in all the samples presumably reflects high biological production. Specifically higher values of $\mathrm{CaCO}_{3}$ is obtained during parts of preglacial stage, middle parts of glacial period and Holocene. Some sites in the Indian Ocean show Pacific pattern, where $\mathrm{CaCO}_{3}$ content is higher during glacials and lower during interglacials (Oba 1969; Naidu 1991), whereas others exhibit Atlantic pattern, where $\mathrm{CaCO}_{3}$ content is generally higher during inter- glacials and lower during glacials (Peterson and Prell 1985; Naidu et al. 1993; Das et al. 2008). Some of the sites show both Atlantic and Pacific patterns (Naidu and Malmgren 1999). High $\mathrm{CaCO}_{3}$ precipitation during glacial period indicates distinct intensification of winter monsoons which led to higher surface productivity in the Arabian Sea (Rai and Das 2011). Decreased $\mathrm{CaCO}_{3}$ precipitation during glacial period is linked to the weakened summer monsoon leading to reduced upwelling (Nair et al. 1989; Narayana et al. 2009). Several studies on (Emeis et al. 1995; Spaulding and Oba 1992; Ivanova et al. 2003; Pattan et al. 2003) the Arabian Sea also observed low productivity during last glacial maximum (LGM). However, Gupta et al. (2005) observed that in the eastern Arabian Sea, $\mathrm{CaCO}_{3}$ content changes do not show a consistent pattern with reference to glacial and interglacial climatic fluctuations. High $\mathrm{CaCO}_{3}$ during preglacial and Holocene periods are related to less terrigenous dilution and enhanced productivity. Moreover, higher contribution of terrigenous matter and lower $\mathrm{CaCO}_{3}$ values during the Last Glacial Period (LGP) suggest greater terrigenous dilution. Sea level during the LGP was between 100 and $120 \mathrm{~m}$ below the present-day level and the rivers were debouching into the sea far away from the present-day coastline (Narayana et al. 2009). This lower sea level also favoured erosion of 
exposed continental shelf and shortened distance of transportation of suspended load of rivers to the deep sea at this location. The terrigenous sediments of the southwestern continental margin of India consist predominantly of river-borne clays, whereas aeolian fraction is negligible (Rao and Rao 1995). The terrigenous input decreases gradually from $\sim 10$ to $\sim 2 \mathrm{ka}$. The low terrigenous input during Holocene, particularly at $\sim 5$ ka suggested weakening of monsoon intensity and stabilized sea level. Pattan et al. (2005) also observed similar results in sediment data of the continental margin of India, southeastern Arabian Sea. The high terrigenous influx during certain ages of the preglacial (MIS 3) stage suggests intensive hydrolysis resulting in enhanced erosion due to increased precipitation. Hence, it appeared that the dilution of $\mathrm{CaCO}_{3}$ in the southeastern Arabian Sea is caused by the influx of terrigenous materials derived from the nearby hinterland.

Several workers used organic carbon as an indicator for paleoproductivity in the eastern Arabian Sea (Thamban et al. 2001; Banakar et al. 2005). Based on this data, some of the workers suggested higher productivity during LGP than in Holocene (Rostek et al. 1997; Schulte et al. 1999; Prabhu and Shankar 2005; Banakar et al. 2005) and correlated it with strong winter monsoon winds. But, Gupta et al. (2005) suggested that the organic carbon content changes in the eastern Arabian Sea were not consistent with the glacial and interglacial conditions. The present investigation at this site shows almost similar variation pattern of TOC with the carbonate for dominant part of the studied section indicating its variability related to the same factors that controlled biogenic productivity.

\subsection{Provenance discrimination of the fine-grained terrigenous sediments}

Clay minerals in the marine sediments are derived from two main sources: one is terrigenous detritus, which contains most of the provenance information; another is authigenic process which may be caused by alteration of volcanic sea floor basement or hydrothermalism. The provenance discrimination of clay minerals requires a detailed understanding of potential source areas, as well as constraints on transport media and processes (Chamley 1989; Steinke et al. 2008). The potential sediment and its transport pathways in the Arabian Sea indicate several source areas, for example, detrital input from Somalia, aeolian contribution from Arabia and Iran-Makran, detrital input from Indus (Himalayan source), Tapti, and Narmada rivers and weathering of Deccan Traps (Western Ghats source), gneissic rocks, laterites
(Precambrian source of southern India) and submarine weathering of Carlsberg Ridge (Nair et al. 1982a, 1982b; Shimmield et al. 1990; Sirocko and Lange 1991; Pederson et al. 1992; Rao and Rao 1995; Sirocko et al. 2000; Kessarkar et al. 2003; Pattan et al 2005; Thamban et al. 2002; Das et al. 2008). The aeolian dust input is an important mechanism of sediment contribution in the southwestern and western Arabian Sea (Debrabant et al. 1991; Das et al. 2008; and others). The Himalayan source is characterized by well crystalline illite and chlorite that are transported by the Indus River to the northern Arabian Sea. The influence of Indus River is largely restricted to the north of Gulf of Kutch because the macro-tidal currents in these zone act as barriers for long shore sediment transport to the south (Nair et al. 1982a, b). The illite crystallinity of the present samples varies between moderate to poor, and the illite chemistry indicates that the illites are slightly $\mathrm{Fe}-\mathrm{Mg}$ rich. The present observations on the illite crystallinity and chemistry data suggest that illite is mostly derived from the southwestern continental margin of India, where Precambrian crystalline rocks are present and have been lateritized at places. Poorly crystalline illites are formed due to intense hydrolysis in the hinterland source area under warm humid climatic conditions. Chauhan and Gujar (1996) reported high illite and chlorite content in the sediments of the southwestern margin of India and identified their source as the waters of the Ganges-Brahmaputra rivers, transported by the Bay of Bengal and intrusion of the southwestern coast during the northeast monsoon. This observation helps in understanding the admixture of Al-rich illite of hinterland with the slightly high $\mathrm{Fe}-\mathrm{Mg}$ rich illite from the Bay of Bengal that caused imperfect matching of illite crystallinity and chemistry in the present samples.

The occurrence of smectite, a weathered and erosional product of basic volcanic rocks indicate the Western Ghats source of western and central India. These detritus are drained into the eastern Arabian Sea by Narmada, Tapti and several other small streams originating from the steep slopes of Western Ghats mountain (discharge $\sim 100 \mathrm{~km}^{3}$ water annually). The Western Ghats mountain range with its elevations up to $\sim 1000 \mathrm{~m}$, plays a major role in controlling the rainfall intensity (annual rainfall intensity $>3000 \mathrm{~mm}$ ) over the west coast of India (Thamban et al. 2002). Kolla et al (1976, 1981) also reported that smectite-rich sediments in the deeper Arabian Sea are derived from the Deccan Traps.

The weathering of gneissic rocks (Precambrian source of southern India) provides high amount of kaolinite, poorly crystalline illite and gibbsite. These gneissic rocks are lateritized at places. 
Intense chemical weathering and leaching of crystalline rocks under tropical humid climate results in the formation of kaolinite and gibbsite (Chamley 1989; Tripathi and Rajamani 2007; Rajamani et al. 2009). Kaolinite, dickite and gibbsite are the most common minerals in the lateritic rocks and soils of southern India (Nair and Mathai 1981). Nair et al. (1982a, 1982b) and Rao and Rao (1995) also found high kaolinite content in the surficial sediments of upper continental slope of southwestern India. These observations indicate that kaolinite in the present core samples are derived from hinterland source rocks and supplied by the fluvial and crossshelf transport processes to the southeastern Arabian Sea. The chlorite content remained moderate throughout the examined section. The chlorite contribution almost similarly matched with the kaolinite contribution indicating similar mechanism of derivation. Several workers also reported chlorite in the surficial sediments along the central and southwestern margin of India (Nair et al. 1982a, 1982b; Rao and Rao 1995, Thamban et al. 2002).

\subsection{Paleoenvironmental implications of clay mineralogy}

The recognition of provenance of detrital clay minerals and its transport pathways to the present site suggest that the late Quaternary climatic conditions which existed on the hinterland dominantly controlled the contribution of clay minerals. Although several factors such as fluvial discharges, sea level, monsoon climate and oceanic circulation may influence deposition of clays, ultimately climatic signals are given more importance for their derivation in the present site, because the present site lies in the tropical belt and experience monsoon climate with seasonally reversing wind patterns and related large changes in precipitation. Climate controlled aridity and humidity in the source area and ultimately the composition of clay minerals. Similar rock types undergoing weathering in different climatic conditions could give rise to different clay mineral assemblages (Deepthy and Balakrishnan 2005). It is also the climatic change that leads to erosion reactivation and reworking of the soils in the source region (Thiry 2000). To correlate clay mineralogy with paleoclimate, the ratios of specific clay minerals are used instead of only individual clay minerals. This will reduce the effect of mutual dilution on clay mineral assemblages. The kaolinite to illite ratio is a suitable proxy for paleoclimatic reconstruction, because kaolinite is normally formed by intense chemical weathering under warm and humid climate, whereas illite is commonly formed due to physical weathering under cool and dry climate. But, illite may have also been derived from alteration of micas under warmer and wetter conditions (Birkeland 1984). The smectite to illite ratio $(\mathrm{Sm} / \mathrm{Il})$ is also considered equally important to decipher paleoclimate because smectite normally forms due to chemical weathering under a warm and humid climate (Ehrmann et al. 2007). During the preglacial period (28-24 ka), climate was warm and southwest monsoon was active. This was well-evidenced by relatively higher values of humidity indices (particularly, K/I ratio). During this period, illite showed poorer crystallinity and was Al-rich. The high biogenic carbonate content during this period also conforms to the intense monsoonal activity. The intensification of monsoon during this period is also reported from the laminated sediments of Pakistan margin (von Rad et al. 1999) and western margin sediments of India (Thamban et al. 2002). The fall in humidity indices to around $\sim 28$ ka may be correlated to the stadial (STADIAL 3.1) condition within the preglacial period (Marine Isotopic Stage 3 ). Lesser contributions of kaolinite and smectite at this age indicate dry period and less chemical weathering of continental rocks. Slightly better crystalline illite with high $\mathrm{Fe}-\mathrm{Mg}$ content also conforms to this observation. The carbonate contents also indicate less biogenic productivity and poor monsoonal activities at this time. Marked fall in the humidity indices recorded at $\sim 22$ ka may be correlated to the LGM. Based on oxygen isotopic data measured in biogenic fossils, reduction of southwestern monsoon wind strength and low precipitation were reported from the western Arabian Sea and equatorial Indian Ocean, respectively during LGM (Prell et al. 1980; Duplessy 1982; Van Campo et al. 1982; Tiwari et al. 2006; Rai and Das 2011; Gunnel 2001a, 2001b). During this period, products of physical weathering have contributed more. The humidity indices typically show higher values during $20-17 \mathrm{ka}$. During this period, the illite shows poorer crystallinity and is Al-rich. The kaolinite and smectite content were nearly doubled. Gibbsite is also found during this interval. All these data together indicate that punctuation of summer monsoon led to precipitation during glacial period and release of products of chemical weathering from the continental region. This may also occur due to fall in sea level because this period corresponds to the late stages of Pleistocene glaciations (Duplessy 1982; Fairbanks 1992). The products of chemical weathering that were deposited on to the shelf region at higher sea level got eroded by rivers and were directly deposited into deeper sea. Additional sediment might also be deposited due to sustained fluvial erosion and long distance retreat of the Western Ghats escarpment (Kale and Shejwalkar 2007). The Western Ghats escarpment has uniformly retreated at an average rate 
of 1-1.5 km Myr ${ }^{-1}$ (Gunnel 2001a, 2001b). Several workers suggested that erosionally driven isostatic uplift of Western Ghats is occurring since the Tertiary (Gunnel 2001a, 2001b; Kale and Shejwalkar 2008). Valdiya (2001) suggests that such activity occurs due to neotectonic resurgence. It is well-established that Western Ghats are predominantly a denudational feature (Gunnell and Radhakrishna 2001; Valdiya and Narayana 2007; Campanile et al. 2008). However, several studies have also indicated that there is no clear relationship between chemical weathering and uplift (White and Blum 1995; Deepthy and Balakrishnan 2005; others). Clay mineral genesis is related to chemical weathering and hence the clay mineralogy of weathering profiles in the hinterland and its contribution into the sea will not directly depend on uplift. The high biogenic carbonate and organic carbon content during the above period may be linked to the intensification of winter monsoons leading to an increased deep-water nutrient injection into photic zone and higher biogenic productivity (Duplessy 1982; Rostek et al. 1997; Cayre and Bard 1999; Singh et al. 2006, 2011). Based on planktic forminiferal data (abundance of Globigerina bulloides and the ratio between $G$. bulloides and G. ruber), Singh et al. (2006, 2011) also recorded increased productivity during the above glacial stage in the eastern and western Arabian Sea and postulated that stronger glacial winter monsoon winds were responsible for the above changes.

During 19 to $16 \mathrm{ka}$, both relatively high and low values of humidity indices are recorded along with the fluctuations of various clay minerals. The carbonate and organic carbon content also fluctuated rapidly. These parameters together indicate that the strength of the monsoon was alternating between strong and weak. The overall lowest values of the humidity indices are observed between 16 and $10 \mathrm{ka}$ indicating lowest intensity of southwest monsoon in the late glacial period. The illite is formed by degradation of gneissic rocks under conditions of limited precipitation. The moderate to good crystalline $\mathrm{Fe}-\mathrm{Mg}$-rich illite also conforms to less hydrolysis at the continental source regions. The terrigenous non-clay mineral (quartz and feldspar) input was very low. Although quartz can be derived from a variety of source rocks under a range of weathering conditions, the drier climatic conditions were more favourable for preservation of feldspar. The higher amount of terrigenous input during this period indicates withdrawal of sea and erosion of sediments that were caught in the continental shelf during high stand of sea. Even towards the end of this drier period, humidity indices were again increasing stepwise indicating variation in intensity of monsoon and late deglaciation.
Holocene is marked by distinct increase in kaolinite contribution and humidity indices, poor illite crystallinity and more of Al-rich illite, indicating summer monsoon intensification. The $\mathrm{CaCO}_{3}$ data, a parameter of biological productivity of this site also indicate intensification of summer monsoons. Based on different proxies, earlier studies indicated intense southwest monsoon during the early Holocene with a maximum at 9 ka (Prell 1984; Van Campo 1986; Naidu and Malmgren 1996; Gupta et al. 2003). Whereas, Thamban et al. (2002) and Singh et al. (2006) reported low intensity of monsoon during the above period and it became intense only after $\sim 9$ ka. During the period, between $\sim 10,400$ and 5000 calibrated years before present, the Northern Hemisphere temperatures peaked and the Indian, southeast Asian and African monsoons reached their maximum 'Holocene Climatic Maximum' (Gupta 2010). Earlier, Alley et al. (1997) and others reported cooling phase at 8.2 ka from Indian subcontinent. However, these changes could not be well-identified in the present study.

Millennial scale variability: Clay mineralogical signatures and clay-based humidity index for the ages $\sim 29.5-28,24.5-23,16-14.8$ and $12.7-11 \mathrm{ka}$, which correspond to H3, H2, H1 and YD events, respectively show moderate correlation. The low values of humidity index $\mathrm{K} / \mathrm{I}$ somewhat shows that either very dry or semi-drier conditions were developed during aforesaid events in this region which resulted in more contribution of products of physical weathering, e.g., illite and chlorite. Mineral kaolinite and occasionally gibbsite which is a product of intense chemical weathering either remained low or decreased in content during the above events. The spike in kaolinite content corresponding to $12.7-15 \mathrm{ka}$ (B-A Event) sandwiched between two lows of Heinrich Events indicates sudden change in climate from dry to warm and humid. The low values of biogenic carbonate and organic carbon also indicates low productivity associated with weak summer monsoons during Heinrich Events. The slightly variable behaviour of clay data may be due to the fact that the responses of clay minerals to the sudden change in climatic conditions are not always instantaneous and the clay mineral assemblage deposited at a particular time is the combined effect of weathering during both older and contemporaneous climate. Cycles of millennial timescale variations have been reported by Sirocko et al. (1996) from the southwest monsoon records of the last deglaciation in the Arabian Sea (cycles of 2200, 1785, 1450 and 1150 years). South-American pollen records also show periodicities similar to the cycles of 2300, 1800, 1300 and 1000 years obtained from the clay mineralogical record (Mommersteeg et al. 1998; cycles of 2200-2300, 
1600-1700, 1400-1500 and 1100-1000 years). Pestiaux et al. (1988) reported suborbital periodicities at 4600 and 2300 years in the Indian Ocean hydrography, which were explained as combination tones of the orbital precessional and obliquity cycles, representing an internal but nonlinear response of the monsoon system to solar forcing (Hagelberg et al. 1994). A similar 2200-year periodicity was reported from Oman margin (Naidu and Malmgren 1995) and attributed to interactions between oceanic circulation changes and atmospheric ${ }^{14} \mathrm{C}$ variations, which show a 2300-year periodicity (Stuiver et al. 1991). Higher frequency periodicities (1800, 1300 and 1000 years) were reported from paleo-temperature variations in the upwelling off west Africa (Eglinton et al. 1992) and from vegetation changes in the southeastern United States. Thus, all the cycles observed in the monsoonal climate appear to be part of global oscillations.

\section{Conclusions}

Variations in the clay mineral assemblages at the core SK-221 during the last $30 \mathrm{kyr}$ indicate the following paleoenvironmental changes in the southeastern Arabian Sea:

- The clay mineral assemblages predominantly consist of illite, kaolinite and chlorite with small amounts of smectite. Illite was the dominant mineral during the glacial period; whereas, kaolinite, chlorite and occasionally gibbsite were found during the preglacial and Holocene periods.

- The clay minerals primarily originated from the hinterland and were supplied by numerous small rivers draining the western India. However, strong reworking and erosion of the Indian continental shelf during glacial period were also partly responsible for their deposition.

- The higher kaolinite/illite, smectite/illite ratios along with poor illite crystallinity indicate strengthened summer monsoon precipitation and weakened winter monsoon during preglacial and Holocene. The high $\mathrm{CaCO}_{3}$ and organic carbon during preglacial and Holocene periods were also related to enhanced biogenic productivity due to strong summer monsoon. In contrast, lower kaolinite/illite, smectite/illite ratios with good illite crystallinity and decreased $\mathrm{CaCO}_{3}$ precipitation indicate a strongly intensified winter monsoon and weakened summer monsoon during glacial period.

- Typically, higher clay mineral ratios and Al-rich poorly crystalline illites were recorded during 20$17 \mathrm{ka}$. The fall of sea level during glacial period led to erosion of sediment from the continental shelf regions that were product of chemical weathering deposited during high sea level and transported to the sea by rivers and wind.

- Clay-based proxies indicated dry to semi-dry conditions during Heinrich Events (H1, H2 and H3) and YD; whereas, the B-A Event was recorded as an abrupt increase in humidity. The above proxies also indicated global monsoonal oscillations in millennial timescale variations of 2300, 1800, 1300 and 1000 years.

\section{Acknowledgements}

The authors are thankful to Director, NCAOR, Goa who has allowed Sujit Sarkar and Prashant Mishra, students of Earth and Planetary Sciences, University of Allahabad, Allahabad to participate in the Sagar Kanya cruise and collect samples for the present study. They thank Mr. Ashish Kesari, University of Allahabad for analysing the samples using XRD and to Dinesh K Ray, Institute of Physics for preparing the samples for AMS analysis. The thoughtful comments of anonymous reviewers helped to improve the quality of the manuscript.

\section{References}

Adatte T, Keller G and Stinnesbeck W 2002 Late Cretaceous to early Paleocene climate and sea-level fluctuations: The Tunisian record; Palaeogeogr. Palaeoclimatol. Palaeoecol. 178 165-196.

Alley R B, Mayewski P A, Sowers T, Stuiver M, Taylor K C and Clark P U 1997 Holocene climatic instability: A prominent, widespread event 8200 years ago; Geology $\mathbf{2 5}$ 483-486.

Banakar V K, Oba T, Chodankar A R, Kuramoto T, Yamamoto M and Minagawa M 2005 Monsoon related changes in sea surface productivity and water column denitrification in the eastern Arabian Sea during the last glacial cycle; Mar. Geol. 219 99-108.

Birkeland P W 1984 Soils and geomorphology (New York: Oxford University Press), 372p.

Biscaye P E 1965 Mineralogy and sedimentation of deep sea clay in the Atlantic Ocean and adjacent sea and oceans; Bull. Geol. Soc. Am. 76 803-832.

Campanile D, Nambiar C G, Bishop P, Widdowson M and Brown R 2008 Sedimentation record in the KonkanKerala Basin: Implications for the evolution of the Western Ghats and the Western Indian passive margin; Basin Res. 20 3-22, doi: 10.1111/j.1365-2117.2007.00341.x.

Cayre O and Bard E 1999 Planktonic foraminiferal and alkenone records of the Last Deglaciation from the Eastern Arabian Sea; Quat. Res. 52 337-342.

Chamley H 1989 Clay sedimentology (Berlin: SpringerVerlag), 623p.

Chamley H 1997 Clay mineral sedimentation in the ocean; In: Soils and sediments, mineralogy and geochemistry (eds) Paquet $\mathrm{H}$ and Clauer $\mathrm{N}$ (Berlin, New York: Springer), pp. 269-302.

Chauhan O S 1994 Influence of macrotidal environment on shelf sedimentation, Gulf of Kachchh, India; Cont. Shelf Res. 14 1477-1493. 
Chauhan O S and Gujar A R 1996 Surficial clay mineral distribution on the southwestern continental margin of India: Evidence of input from the Bay of Bengal; Cont. Shelf Res. 16 321-333.

Cullen J L and Prell W L 1984 Planktonic foraminifera of the Northern Indian Ocean: Distribution and preservation in surface sediments; Mar. Micropaleontol. 9 1-52.

Das S S, Maurya A S, Pandey A C, Uday Bhan and Rai A K 2008 Influence of sediment source and monsoonal variations on the late Quaternary clay mineral assemblages at ODP site 728A, northwestern Arabian Sea; Curr. Sci. 95 1320-1326.

Debrabant P, Krissek L, Bouquillon A and Chamley H 1991 Clay mineralogy of Neogene sediments of the western Arabian Sea: Mineral abundances and palaeoenvironmental implications; In: Proceedings ODP, Scientific Results, Leg\#117 (eds) Prell W L et al., College Station, TX, pp. $183-196$.

Deepthy R and Balakrishnan S 2005 Climatic control on clay mineral formation: Evidence from weathering profiles developed on either side of the Western Ghats; J. Earth Syst. Sci. 114 545-556.

Dou Y, Yang S, Liu Z, Clift P D, Yu H, Berne S and Shi X 2010 Clay mineral evolution in the central Okinawa Trough since 28 ka: Implications for sediment provenance and paleoenvironmental change; Palaeogeogr. Palaeoclimatol. Palaeoecol. 288 108-117.

Duplessy J C 1982 Glacial to interglacial contrast in the northern Indian Ocean; Nature 295 494-498.

Dutta K, Bhushan R and Somayajulu B L K $2001 \Delta$ - $R$ correction values in the Northern Indian Ocean; Radiocarbon 43(2a) 483-488.

Eglinton G, Bradshaw S, Resell A, Sarnthein M, Pflaumann U and Tiedemann R 1992 Molecular record of secular sea surface temperature changes on 100-year timescales for glacial terminations I, II and IV; Nature 356 423-426.

Ehrmann W, Schmiedl G, Hamann Y, Kuhnt T, Hembleben C and Siebel W 2007 Clay minerals in late glacial and Holocene sediments of the northern and southern Aegean Sea; Palaeogeogr. Palaeoclimatol. Palaeoecol. 249 36-57.

Emeis K C, Anderson D M, Doose H, Kroon D and SchultzBull D 1995 Sea-surface temperature and history of monsoon upwelling in the northwest Arabian Sea during the last 500,000 years; Quat. Res. 43 355-361.

Esquevin J 1969 Influence de la composition chimique des illites sur le cristllinite; Bull. Centre Rechcherche PauSNPA 3 147-154.

Fairbanks R G 1992 Barbados sea level and Th/U 14C calibration; IGBP PAGES/World Data Center-A for Paleoclimatology Data Contribution Series 92-020. NOAA/NGDC Paleoclimatology Program, Boulder, CO.

Gaudette H E, Flight W R, Toner L and Folger D W 1974 An inexpensive titration method for the determination of organic carbon in recent sediments; J. Sedim. Petrol. 44 249-253.

Gingele F X 1996 Holocene climatic optimum in southwest Africa - Evidence from the marine clay mineral record; Palaeogeogr. Palaeoclimatol. Palaeoecol. 122 77-87.

Griffin J, Windom H and Goldberg E D 1968 The distribution of clay minerals in the word ocean; Deep-Sea Res. 15 433-459.

Grim R E 1968 Clay mineralogy (New York: McGraw Hill), 596p.

Gunnel Y 2001a Dynamics and kinematics of rifting and uplift at the western continental margin of India: Insights from geophysical and numerical models; In: Sahyadri: The great escarpment of the Indian subcontinent (eds) Gunnell Y and Radhakrishna B P, Geol. Soc. India Memoir 47 475-496.
Gunnel Y 2001b Environmental changes in the Western Ghats during the Quaternary; In: Sahyadri: The great escarpment of the Indian subcontinent (eds) Gunnell Y and Radhakrishna B P, Geol. Soc. India Memoir 47 817-832.

Gunnell Y and Radhakrishna B P (eds) 2001 Sahyadri: The great escarpment of the Indian subcontinent, Geol. Soc. India Memoir 47 1054p.

Gupta A K 2010 Evolution of the Indian monsoon since late Miocene intensification - marine and land proxy records; J. Paleontol. Soc. India 55 1-9.

Gupta A K, Anderson D M and Overpeck J T 2003 Abrupt changes in the Asian southwest monsoon during the Holocene and their links to the North Atlantic Ocean; Nature 421 354-357.

Gupta M V S, Naidu P D, Haake B G and Schiebel R 2005 Carbonate and carbon fluctuations in the eastern Arabian Sea over 140 ka: Implications on productivity changes; Deep-Sea Res. II 52 1981-1993.

Hagelberg T K, Bond G and deMenocal P 1994 Milankovitch band forcing of sub-Milankovitch climate variability during the Pleistocene; Paleoceanography 9 545-558.

Honjo S, Dymond D, Prell W L and Ittekkot V 1999 Monsoon controlled export fluxes to the interior of the Arabian Sea; U.S. JGOFS 1994-95 Experiment; Deep-Sea Res. II 46 1859-1902.

Hughen K A, Baillie M G L and Bard E 2004 Marine radiocarbon age calibration, 0-26 cal kyr BP; Radiocarbon 46 1059-1086.

Ivanova E, Schiebel R, Singh A D, Schmied G, Niebler H S and Hemleben Ch 2003 Primary production in the Arabian Sea during the last 135,000 years; Palaeogeogr. Palaeoclimatol. Palaeoecol. 197 61-82.

Kale V S and Shejwalkar N 2007 Western Ghat escarpment evolution in the Deccan Basalt Province: Geomorphic observations based on DEM analysis; J. Geol. Soc. India 70 459-473.

Kale V S and Shejwalkar N 2008 Uplift along the western margin of the Deccan Basalt Province: Is there any geomorphometric evidence?; J. Earth Syst. Sci. 117 959-971.

Kessarkar P M, Rao V P, Ahmad S M and Anil Babu G 2003 Clay minerals and $\mathrm{Sr}-\mathrm{Nd}$ isotopes of the sediments along the western margin of India and their implication for sediment provenance; Mar. Geol. 202 55-69.

Kolla V, Henderson L and Biscaye P E 1976 Clay mineralogy and sedimentation in the western Indian Ocean; Deep-Sea Res. Oceanogr. Abstr. 23/10 949-961.

Kolla V, Kostecki J A, Robinson F, Biscaye P and Ray P K 1981 Distribution and origin of clay minerals and quartz in surface sediments of the Arabian Sea; J. Sedim. Petrol. $51563-569$.

Mallison D J, Flower B, Hine A, Brooks G and Garza R M 2003 Paleoclimatic implications of high latitude precession scale mineralogic fluctuations during early Oligocene Antarctic glaciation: The Great Australian Bight record; Global Planet. Change 39 257-269.

Mommersteeg H J P M, Loutre M F, Baert E and Berger A 1998 Orbital forcing and cyclic abrupt climatic change during the last 170,000 years. Evidence from high resolution palynological records of the Colombian eastern Cordillera, In: Vegetation development and cyclic and abrupt climatic change during Late Quaternary (ed.) Mommersteeg H J P M, Unpublished Ph.D. thesis, University of Amsterdam.

Moore D M and Reynolds R C Jr 1997 X-ray diffraction and the identification and analysis of clay minerals, 2nd edn (Oxford: Oxford University Press), 378p.

Naidu P D 1991 Glacial to interglacial contrasts in the calcium carbonate content and influence of Indus discharge 
in two eastern Arabian Sea cores; Palaeogeogr. Palaeoclimatol. Palaeoecol. 86 255-263.

Naidu P D and Malmgren B A 1995 A 2200 years periodicity in the Asian Monsoon System; Geophys. Res. Lett. 22 2361-2364.

Naidu P D and Malmgren B A 1996 A high-resolution record of late Quaternary upwelling along the Oman margin, Arabian Sea, based on planktic foraminifera; Paleoceanography 11 129-140.

Naidu P D and Malmgren B A 1999 Quaternary carbonate record from the equatorial Indian Ocean and its relationship with productivity changes. Mar. Geol. 161 49-62.

Naidu A S and Shankar R 1999 Palaeomonsoon history during Late Quaternary: Results of a pilot study on sediments from the Laccadive trough southeastern Arabian Sea; J. Geol. Soc. India 53 401-406.

Naidu P D, Malmgren B A and Bornmalm L 1993 Quaternary history of calcium carbonate fluctuations in the western equatorial Indian Ocean (Somali Basin); Paleogeogr. Paleoclimatol. Paleoecol. 103 21-30.

Nair A M and Mathai T 1981 Geochemical trends in some laterite profiles of north Kerala; In: Proc. Intr. Sem. Lateritisation processes (Trivandrum-1979) (New Delhi: Oxford and IBH Publishing Co.), pp. 114-119.

Nair R R, Hashimi N H and Rao V P 1982a On the possibility of high velocity tidal streams as dynamic barriers to longshore sediment transport: Evidence from the continental shelf of the Gulf of Kutch, India; Mar. Geol. 47 $77-86$.

Nair R R, Hashimi N H and Rao V P 1982b Distribution and dispersal of clay minerals on the western continental shelf of India; Mar. Geol. 50 Ml-M9.

Nair R R, Ittekot V, Manganini S J, Ramswamy V, Haake B, Degens E T, Desai B N and Honjo S 1989 Increased particle fluxes to the oceans related to the monsoons; Nature $338749-751$.

Narayana A C, Naidu P D, Shinu N, Nagabhushanam P and Sukhija B S 2009 Carbonate and organic carbon content changes over last $20 \mathrm{ka}$ in the southeastern Arabian Sea: Paleoceanographic implications; Quat. Int. 206 72-77.

Oba T 1969 Science Report, 2nd Series (Geology) (2) Biostratigraphy and isotopic paleotemperature of some deepsea cores from the Indian Ocean; Tohoka University, 41 129-195.

Pattan J N, Masuzawa T, Naidu P D, Parthiban G and Yamamoto M 2003 Productivity fluctuations in the southeastern Arabian Sea during the last $140 \mathrm{ka}$; Paleogeogr. Paleoclimatol. Paleoecol. 193 575-590.

Pattan J N, Masuzawa T and Yamamoto M 2005 Variations in terrigenous sediment discharge in a sediment core from southeastern Arabian Sea during the last 140 ka; Curr. Sci. 89 1421-1425.

Pederson T, Shimmield G B and Price N B 1992 Lack of enhanced preservation of organic matter in sediments under the oxygen minimum on the Oman Margin; Geochim. Cosmochim. Acta 56 545-551.

Pestiaux P, van der Mersch I, Berger A and Duplessy J C 1988 Paleoclimate variability at frequencies ranging from 1 cycle per 10,000 years to 1 cycle per 1000 years: Evidence for nonlinear behaviour of the climate system; Climatic Change 12 9-37.

Peterson L C and Prell W L 1985 Carbonate preservation and rates of climatic change: An 800 ka record from the Indian Ocean. In: The carbon cycle and atmospheric $\mathrm{CO}_{2}$ : Natural variations Archean to present (eds) Sundquist E and Broecker W S, Geophysical Monograph Series. American Geophysical Union, Washington D.C., 32 251-270.
Prabhu C N and Shankar R 2005 Palaeoproductivity of the eastern Arabian Sea during the past 200 ka: A multiproxy investigation; Deep-Sea Res. II 52 1994-2002.

Prell W L 1984 Variation of monsoonal upwelling: A response to changing solar radiation; In: Climate processes and climate sensitivity (eds) Hansen J E and Takahashi T, Geophysical Monograph, American Geophysical Union, Washington, D.C., pp. 48-57.

Prell W L, Hutson W H, Williams D F, Allan W H, Geitzenauer B K and Molfino B 1980 Surface circulation of the Indian Ocean during the last glacial maximum, approximately 18,000 yr B.P., Quat. Res. 14 309-336.

Rai A K and Das S S 2011 Late Quaternary changes in surface productivity and oxygen minimum zone (OMZ) in the northwestern Arabian Sea: Micropaleontologic and sedimentary record at ODP site 728A; J. Earth Syst. Sci. $120113-121$.

Rajamani V, Tripathi J K and Malviya V 2009 Weathering of lower crustal rocks in the Kaveri river catchment, southern India: Implication to sediment geochemistry; Chem. Geol. 265 410-419.

Rao V P and Rao B R 1995 Provenance and distribtuion of clay minerals in the sediments of the western continental shelf and slope of India; Cont. Shelf Res. 15 1757-1771.

Rao V P and Wagle B G 1997 Geomorphology and surficial geology of the western continental shelf and slope of India: A review; Curr. Sci. 73 330-350.

Rea D K and Leinen M 1988 Asian aridity and the zonal westerlies: Late Pleistocene and Holocene record of eolian deposition in the Northwest Pacific Ocean; Palaeogeogr. Palaeoclimatol. Palaeoecol. 66 1-8.

Robert C and Kennett J P 1997 Antarctic continental weathering changes during Eocene-Oligocene cryosphere expansion: Clay mineral and oxygen isotope evidence; Geology 25 587-590.

Rostek F, Bard E, Beafort L, Sonzogni C and Ganssen G 1997 Sea surface temperature and productivity record for the past $240 \mathrm{ka}$ in the Arabian Sea; Deep-Sea Res. II 44 1461-1480.

Schulte S, Rostek F, Bard E, Rullkotter J and Marchal O 1999 Variation of oxygen minimum and primary productivity recorded in sediments of the Arabian Sea; Earth Planet. Sci. Lett. 177 209-218.

Schulz M and Stattegger K 1997 Spectrum: Spectral analysis of unevenly spaced paleoclimatic time series; Comput. Geosci. 23(9) 929-945.

Shetye S R, Gouveia A D, Shenoi S S C, Sunder D, Michael G S, Almeida A M and Santanam K 1990 Hydrography and circulation of the west coast of India during the southwest monsoon 1987; J. Mar. Res. 48 359-378.

Shimmield G B, Mowbray S R and Weedon G P 1990 A 350 ka history of the Indian southwest monsoon: Evidence from deep sea cores, northwest Arabian Sea; Transactions of the Royal Society of Edinburgh; Earth Sci. 81 289-299.

Singer A 1984 The palaeoclimatic interpretation of clay minerals in sediments - a review; Earth Sci. Rev. 21 251-293.

Singh A D, Kroon D and Ganeshram R S 2006 Millennial scale variations in productivity and OMZ intensity in the eastern Arabian Sea; J. Geol. Soc. India 68 369-377.

Singh A D, Jung S J A, Darling K, Geneshram R S, Ivanochko T and Kroon D 2011 Productivity collapses in the Arabian Sea during glacial cold phases; Paleoceanography; doi: 10.1029/2009PA001923.

Sirocko F and Lange H 1991 Clay accumulation rates in the Arabian Sea during the late Quaternary; Mar. Geol. 97 105-119. 
Sirocko F, Garbe-Schonberg D, McIntyre A and Molfino B 1996 Teleconnections between the subtropical monsoons and high-latitude climates during the last deglaciation; Science 272 526-529.

Sirocko F, Garbe-Schönberg D and Devey C 2000 Processes controlling trace element geochemistry of Arabian Sea sediments during the last 25,000 years; Global Planet. Change 26 217-303.

Southon J, Kashgarian M, Fontugne M, Metivier B and Yim W W S 2002 Marine reservoir corrections for the Indian Ocean and Southeast Asia; Radiocarbon 44 167-180.

Spaulding S A and Oba T 1992 Association of late Pleistocene Calcareous Nannofossil Assemblages and ${ }^{18} \mathrm{O}$ and ${ }^{13} \mathrm{C}$ Isotopic Changes, ODP Leg 117, Oman Margin, Arabian Sea. Memoirs Science - Geology, University of Padova XLIII, pp. 389-407.

Steinke S, Hanebuth T J J, Vogt C and Stattegger K 2008 Sea level induced variations in clay mineral composition in the southwestern South China Sea over the past 17000 yr; Mar. Geol. 250 199-210.

Stuiver M and Polach H A 1977 Discussion: Reporting of ${ }^{14} \mathrm{C}$ data; Radiocarbon 19(3) 355-363.

Stuiver M and Reimer P J 1993 Extended ${ }^{14} \mathrm{C}$ database and revised CALIB radiocarbon calibration program; Radiocarbon 35 215-230.

Stuiver M, Branziunas T F, Becker B and Kromer B 1991 Climatic, solar, oceanic, and geomagnetic influences on late-glacial and holocene atmospheric ${ }^{14} \mathrm{C}^{12} \mathrm{C}$ change; Quat. Res. 35 1-24.

Thamban M, Rao V P, Schneider R and Grootes P M 2001 Glacial to Holocene fluctuations in hydrography and productivity along the southwestern continental margin of India; Paleogeogr. Paleoclimatol. Paleoecol. 165 113-127.

Thamban M, Rao V P and Schneider R R 2002 Reconstruction of late Quaternary monsoon oscillations based on clay mineral proxies using sediment cores from the western margin of India; Mar. Geol. 186 527-539.
Thiry M 2000 Palaeoclimatic interpretation of clay minerals in marine deposits: An outlook from the continental origin; Earth Sci. Rev. 49 201-221.

Tiwari M, Ramesh R, Somayajulu B L K, Jull A J T and Burr G S 2006 Paleomonsoon precipitation deduced from a sediment core from the equatorial Indian Ocean; GeoMar. Lett. 26 23-30; doi: 10.1007/s00367-005-0012-0.

Tripathi J K and Rajamani V 2007 Geochemistry and origin of ferruginous nodules in weathered granodioritic gneisses, Mysore plateau, southern India; Geochim. Cosmochim. Acta 71 1674-1688.

Valdiya K S 2001 Tectonic resurgence of the Mysore plateau and surrounding regions in cratonic southern India; Curr. Sci. 81 1068-1090.

Valdiya K S and Narayana A C 2007 River response to neotectonic activity: Example from Kerala, India; J. Geol. Soc. India 70 427-443.

Van Campo E 1986 Monsoon fluctuations in two $20000 \mathrm{yr}$ B.P. Oxygen-isotope/pollen records off southwest India; Quat. Res. 26 376-388.

Van Campo E, Duplessy J C and Rossgnol-Strick M 1982 Climatic conditions deduced from a 150 ky. Oxygen isotope-pollen record from Arabian Sea; Nature 296 $56-59$.

von Rad U, Schulz H, Riech V, den Dulk M, Berner U and Sirocko F 1999 Multiple monsoon-controlled breakdown of oxygen-minimum conditions during the past 30,000 years documented in laminated sediments off Pakistan; Palaeogeogr. Palaeoclimatol. Palaeoecol. 152 129-161.

White A F and Blum A E 1995 Effects of climate on chemical weathering in watersheds; Geochim. Cosmochim. Acta $\mathbf{5 9}$ 1729-1747.

Zhifei L, Trentesaux A and Clemens S C 2003 Quaternary clay mineralogy in the northern South China Sea (ODP site 1146): Implications for oceanic current transport and east Asian monsoon evolution; Sci. China (series D) 46/12 1223-1235. 